\title{
Concert and Dance: the foundations of black jazz in South Africa between the twenties and the early forties
}

\author{
CHRISTOPHER BALLANTINE
}

The explosive development of a jazz-band tradition in South African cities from the 1920 s - closely allied to the equally rapid maturation of a vaudeville tradition which has been in existence at least since the First World War - is one of the most astonishing features of urban-black culture in that country in the first half of the century. Surrounded by myriad other musics - styles forged by migrant workers; traditional styles transplanted from the countryside to the mines; petty bourgeois choral song; music of the church and of western-classical provenance - jazz and vaudeville quickly established themselves as the music which represented and articulated the hopes and aspirations of the most deeply urbanised sectors of the African working class.

This did not happen without fierce controversy. Around, and indeed within, this generalised 'jazzing' subculture were played out the frequently contradictory and overlapping strategies and inclinations of urban blacks: at one moment conciliatory, at another oppositional; now conservative, then radical; rooted in the politics of petty bourgeois assimilationism, or in those of an increasingly militant working-class consciousness. Seldom is it possible to disentangle the complex overlay of symbolic representations within this subculture, in such a way as to produce a simple correspondence of musical idiom to any of the contradictory, nascent class formations in urban-black South African society of the time. Stated more concretely, this means that although one can discern the existence both of different class tendencies and different musical genres, the relationship between economic class and musical genre is not straightforward: competing classes might support the same genre, or one class might identify with different, apparently contradictory, genres.

This complex state of affairs is not confined to music: it is one aspect of a more general problem in the relationship between class and culture in South Africa. Recent South African historiography has brought this problem to light. Summarising such findings, Marks and Rathbone, for instance, have argued that it is 'impossible to consider African working-class culture and consciousness as in any sense watertight or closed off from the rest of the black population' (Marks and Rathbone 1982, p. 2); and Bozzoli has concluded that '[w]hile there may be econ- 
omic classes in the making in South Africa, there have been few "class cultures" " (Bozzoli 1983, p. 40). One reason for this would seem to lie in the sheer physical nature of the ghetto, the microcosm where 'classes get squashed together and lose their sharp edges of distinction'; so 'interests fluctuate' (Couzens 1979, p. 99). Another would seem to derive more specifically from the dialectics of racism, where, because of 'the racial barriers to ... social progress and economic betterment', the black section of the petty bourgeoisie has often been impelled 'to align "downwards" and seek the political support of the black lower classes, emphasising a racial commonality' (Sole 1984, p. 55).

The crucible in which black jazz developed in South Africa was the performing and participating convention known locally as 'Concert and Dance'. Typically, it belonged indoors and to the night. Hounded not only by the hated pass laws but also by night-curfew regulations, and lacking adequate public transport, Africans living in the cities devised a variety of institutions capable of sustaining indoor entertainment throughout the night. 'In spite of the trials and tribulations, segregation, oppression and poverty,' wrote Johannesburg arts columnist Walter Nhlapo in 1936, 'efforts are continually made to make life sweet and brilliant' (Bantu World [hereafter referred to as $B W], 15$ February 1936). The most visible, as well as the most lustrous, of these efforts was the Concert and Dance - characteristically a vaudeville entertainment from $8 \mathrm{p} . \mathrm{m}$. to midnight, followed immediately by a dance which ended at $4 \mathrm{a} . \mathrm{m}$. (see Figure 1). Through this institution - hosted as it was in venues ranging from ramshackle halls in the black townships, to fashionable centres such as Johannesburg's Bantu Men's Social Centre (BMSC) or the Ritz Palais de Dance - passed all of South Africa's greatest jazz and vaudeville artists. It was a crucible in which the two styles were seldom totally distinct; instead, despite some obvious differences, they fed off each other, at times in a relationship that was quite symbiotic. Edward Sililo, who played trumpet with the Jazz Maniacs one of the country's legendary bands - during this period, recalls that the music of the troupes was 'very, very close' to that of the bands: not least 'because most of the songs they played, the bands were playing. They used to come to the bands to ask for the lyrics of the numbers, and then they'd sing these things' (Sililo 1986). In truth, there was often a structural connection between bands and vaudeville companies: a particular band might regularly appear on the same bill as a particular troupe, provide musical backing for certain parts of the troupe's programme, add additional - sometimes essential - members to the cast from their own ranks, and share the same management. ${ }^{1}$

Whence did this repertoire derive? Broadly, from two huge, complex source areas - the one mainly American, the other mainly local - which were absorbed into the repertoire in different ways and in different proportions. Of the two, the American source accounted for what was by far the larger share of the repertoire. It is to this source, then, that we turn our attention first.

For several decades, urban Africans were held in thrall by American culture but above all by the activities and achievements of blacks in that society. Where American culture fascinated, black American culture infatuated. The ways in which this infatuation was expressed, and the uses to which it was put, provide an illuminating insight into some of the psycho-social dynamics of Africans in South 


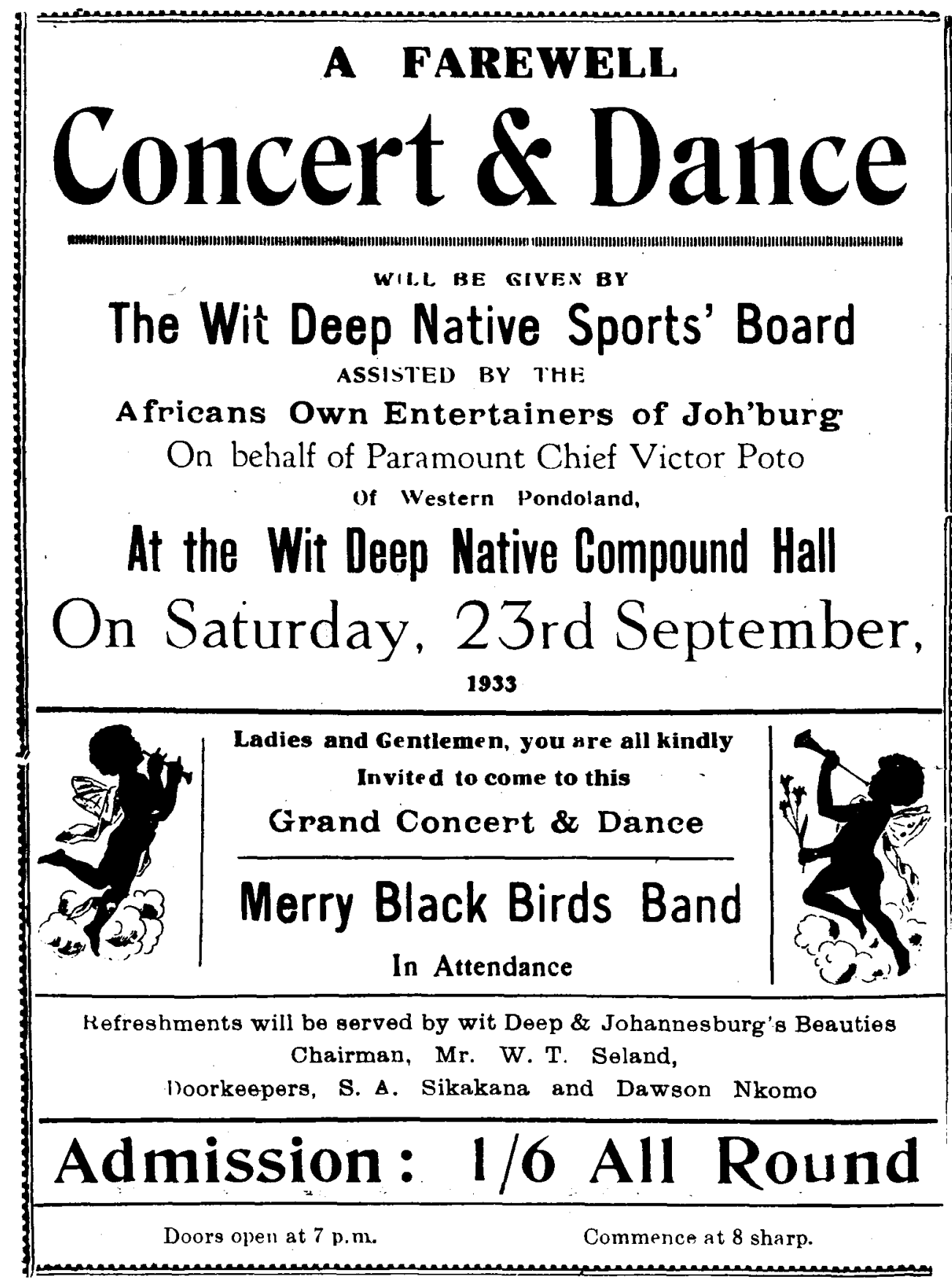

Figure 1. This 1933 poster advertises a Concert and Dance featuring two of the leading ensembles of the time: the Merry Blackbirds (a dance band) and the Africans' Own Entertainers (a vaudeville group). (Picture from: J.H. Pim Papers, Department of Historical Papers, Library of the University of the Witwatersrand.) 
African cities during the approximately two decades under review. Most obviously, this infatuation furnished inspiration: examples for imitation, standards to be striven for, and exhortations to achievement. Invoking the example of 'black stars such as the late Florence Mills, Layton and Johnstone . . . Paul Robeson and many others', and noting that many African children with 'a burning love of music' were 'struggling against the limitations imposed by poverty', a columnist for Umteteli wa Bantu offered these words of encouragement in 1930:

My opinion, based upon exceptionally intimate experience spread over some years, is that the musical talent of the Bantu is as pronounced as that of the American Negro. It is unfortunate that the Natives of South Africa are themselves unaware of their musical talent. (Umteteli wa Bantu [hereafter referred to as UWB], 25 January 1930.) ${ }^{2}$

Such intimations were commonplace and insistent. Indeed, eleven years later Wilfred Sentso, famous vaudeville artist, jazz-band leader, composer and educationist, wrote in the same paper:

Today in the playing of musical instruments you find many Negroes on the top: Coleman Hawkins, Fats Waller, Duke Ellington and Paul Dunbar are but only a few of some outstanding Negro instrumentalists ... We can do it here too! (UWB, 18 January 1941) ${ }^{3}$

Indeed, in their own various and different ways, most were already attempting to do it here too. When Pixley's Midnight Follies 'tried to imitate the American crooning twang', or the African Theatrical Syndicate 'with painted lips and faces smeared jet black, imitated Negro crooners'; when the Mercury Stars of Pretoria 'kept the audience cheerful with the latest stunts from America', or a crowd turned up to watch a demonstration of 'Susie Q - latest dance craze - a Harlem creation!' to music provided by the much-admired Rhythm Kings Band under J.C.P. Mavimbela; when the influential commentator Walter Nhlapo proclaimed himself to be among "the followers of "le jazz hot" ' or noted that the great blues and boogiewoogie pianist Sullivan Mphahlele had been 'an ardent admirer and imitator of the late Fats Waller' - at these and countless other moments notice was being given that not merely individual performers or styles, but an entire subculture, were in the process of being emulated; and that the hope might materialise that Johannesburg, or any other South African city for that matter, would 'one day develop a Harlem of its own which will compare with New York Harlem' (UWB 14, 21 January 1939; $B W, 29$ August 1942; UWB, 4 September 1937, 1 January 1939, 22 January 1944, 3 April 1937).

The premise upon which these exhortations and emulations were based, was the confident assertion of a racial and cultural identity between blacks at home and in the United States. People of colour in the USA - as an editorial in Umteteli insisted in 1932 - were 'Africans in America'; therefore their achievements were a source of very great encouragement to 'Africans in Africa'. Thus the 'soul-moving' vaudeville duo, Layton and Johnstone, though American, were in truth 'of African origin'; by a similar logic, the classical composer Samuel Coleridge-Taylor, though he was born, lived and died in the south of England, was saluted as a 'West African composer'. Just as significant, it was 'a fact that the greatest American works of music, the works that will live, have been influenced chiefly by African melodies and rhythms' (UWB, 29 October 1932; Ilanga Lase Natal [hereafter referred to as ILN], 9 September 1932; UWB, 11 November 1933).

If infatuation with the United States provided the inspiration and the examples, it also set the standards and furnished a means by which local artists could be 
deemed to have succeeded. Favourable comparison with an individual, group or style in the USA was the ultimate stamp of approval. For the top performers, such accolades were common. Peter Rezant, leader of what many considered to be the country's most prestigious dance band - the Merry Blackbirds (see Figure 2) remembers that he used to feel immense pride when audiences confirmed that they could detect 'no difference' between his band's performance of a number, and the way that number sounded on an imported record (Rezant 1984). Though their greatest rivals, the Jazz Maniacs (see Figure 3), were less accomplished readers than the Merry Blackbirds and therefore often learnt pieces directly from recordings, that did not prevent them from achieving the same standards or receiving similar compliments. As Dale Quaker, himself a bandleader in the early forties, recalls:

For instance, you take a song like 'The Woodchopper's Ball'. You know, the way the Maniacs used to play that, it was exactly like the American bands used to play it. Type of fellows who could listen to a thing and then play it. And you wouldn't be able to make out the difference - whether they're playing from an orchestration or not. They were good at that type of thing. (Quaker 1986)

Indeed, Peter Rezant - though he speaks of his greatest rivals - is keen to remember assertions that the Jazz Maniacs played that number even better than the Americans:

What they couldn't read off the score they would buy the record, and try and play all those difficult solos of the big professional men, like for instance Woody Herman's 'Woodchopper's Ball'. They play like one white musician said to me one day, he says, 'You know the way I heard those fellas play "The Woodchopper's Ball", I would say that it sounded better than on the record!' That's how they played - they played very well. (Rezant 1980)

Such attainments often left audiences incredulous. In 1936, the Merry Blackbirds appeared with De Pitch Black Follies, the country's leading vaudeville troupe, at the British Empire Exhibition in Johannesburg; the reported response of the amazed crowd was to dismiss them, saying 'Agh, those are Negroes from America!' (Drum, May 1956).

When it came to the handing out of accolades, comparisons were there in plentiful supply, each time doing duty as a kind of graduation certificate. In 1940, when a trio consisting of Solomon 'Zuluboy' Cele (see Figure 4), leader of the Jazz Maniacs (on saxophone and clarinet), Wilfred Sentso, leader of the Synco Fans troupe (on piano) and Kenneth McBein, temporarily with the Jazz Maniacs (on drums), appeared with the Synco Schools troupe, Walter Nhlapo found this group similar to that of Louis Armstrong and the Lyn Murray Choristers (whose 1938 recording of four spirituals he presumably had in mind); a year later he compared the newly-formed Gay Gaeities to the Mills Brothers, and not long after announced that an ensemble of 'girls' within De Pitch Black Follies 'would be praised by the Peters Sisters, Duncan Sisters, Andrews Sisters and the King Sisters'. Around the same years, tap-dancing duo Jubilation and Nice - also members of De Pitch Black Follies - were hailed as the South African Nicholas Brothers, while the versatile Jubilation's guttural singing was described as 'Armstrongian' and hence seen as a local example of this 'most wonderful achievement of a voice'. Outstanding soloists included Pitch Black Follies and Synco Fans vocalist, Emily Kwenane, a veritable Bessie Smith 'if she would only turn a blues singer' (or a Teddy Grace if she wouldn't), and the wonderful Sullivan Mphahlele, who would 'challenge ... and 


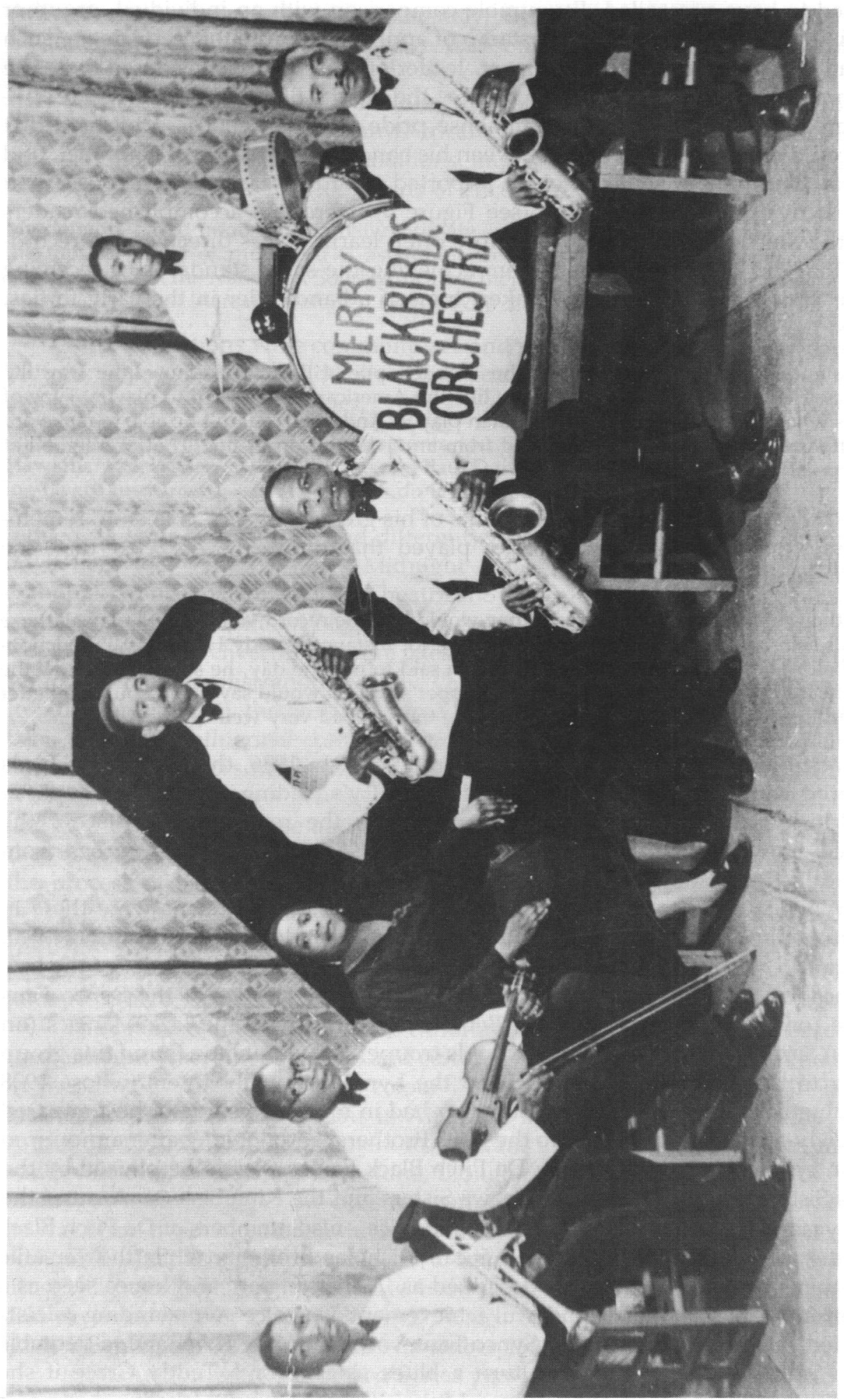

ह

ㅍ

.

ज

$\stackrel{\Xi}{*}$

इ்

E

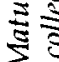

$\overline{5}$

電

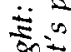

象

온

$\pm$

돈

至

$\infty$

oิ

t)

$\hat{\sigma}=$

S.

ह

ㄹ

$\pm \equiv$

क

ฐ

$\vec{\Xi}$

$\$ \overline{\mathrm{N}}$

28

롤

홍

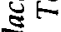

क

플

$\sum^{5}$

롤

i

$\stackrel{5}{5}$

$\infty$ 


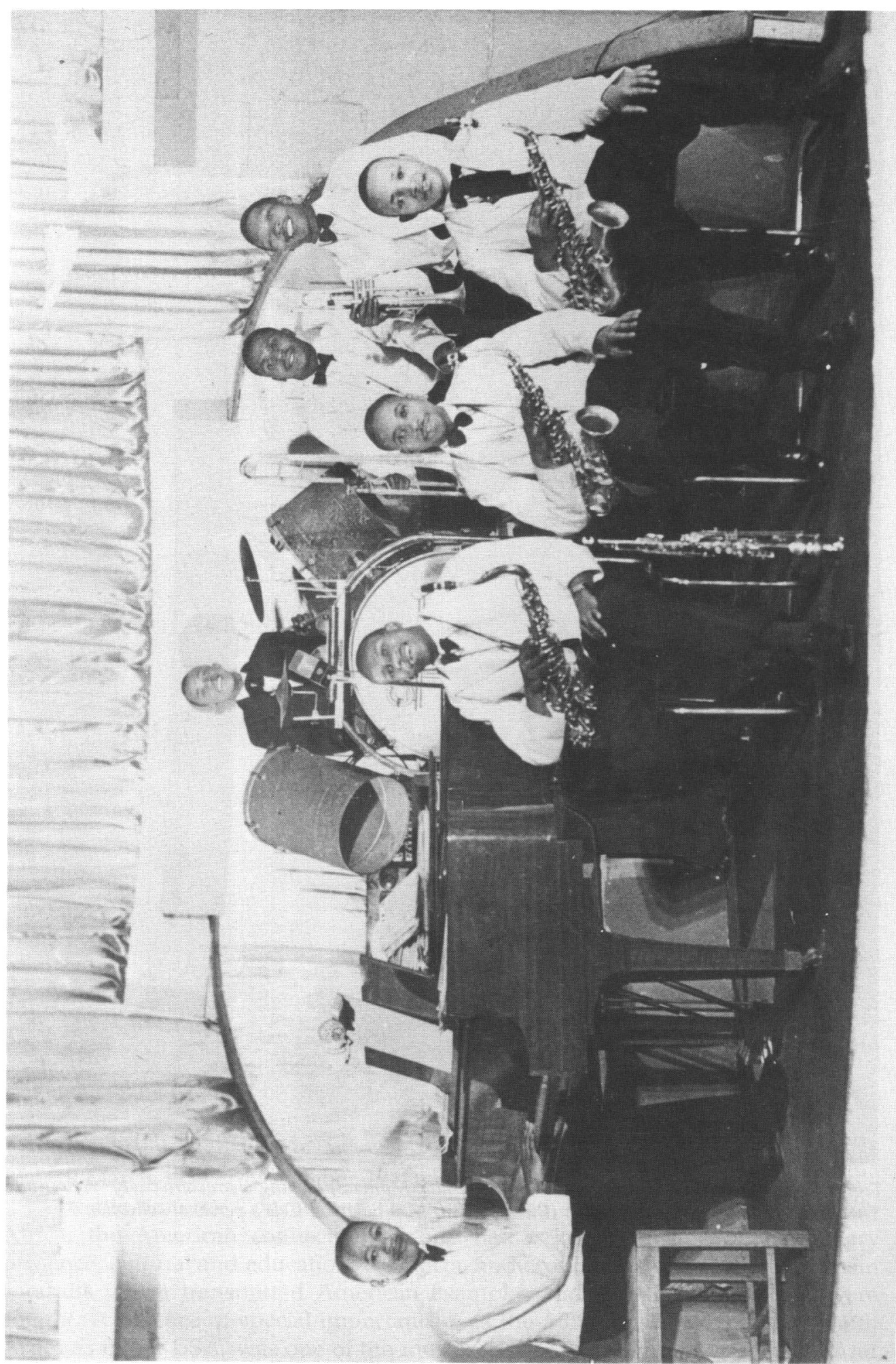

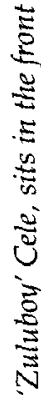

홀

का

के

हु

폰

过

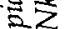

푼

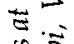

क $\frac{5}{5}$

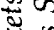

苋

है है

용

कis

$2 \%$

롤

ह

के

폰

赵

离

5 $\frac{9}{2}$

焉

롭

아유

홍

可

$\Xi \approx$

$\infty$

s

竞莕

N

싱

룬

के

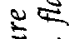

这

昰芯 


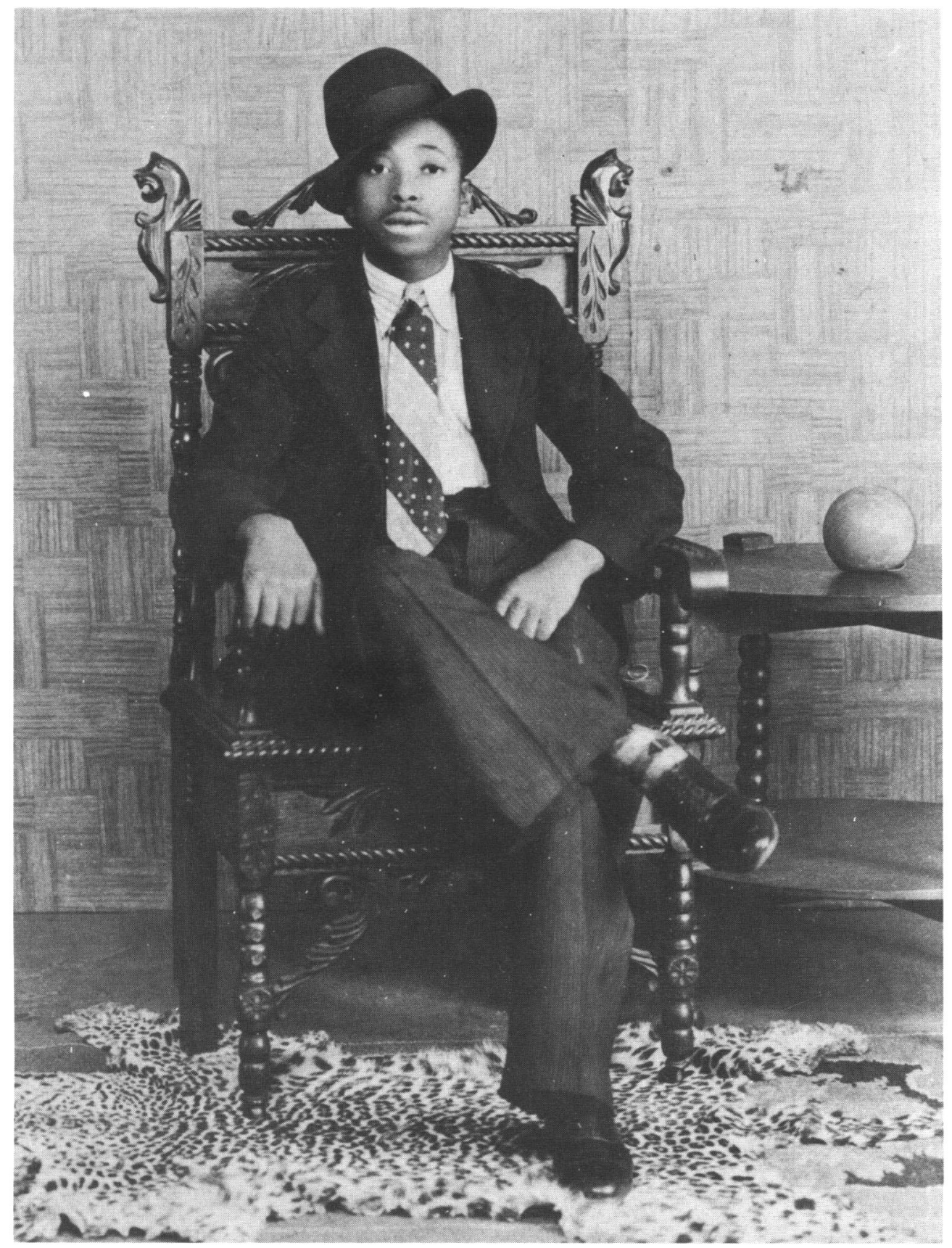

Figure 4. Solomon 'Zuluboy' Cele, leader of the Jazz Maniacs, looking characteristicaly 'American'. The picture was taken around 1942. (Picture from: Mrs Solomon Cele's personal collection.) 
frighten every pianist with his fingers'. He played like Fats Waller, was known as 'Fats Waller', and even died the same day as Fats Waller ( $B W, 21$ September 1940, 4 October 1941, 13 November 1933; ILN, 9 December 1944; BW, 28 November 1942, 22 January 1944; UWB, 22 January 1944).

American accolades were found even for the most eccentric performers. Toko Khampepe, leader of the Bantu Revue Follies and pianist extraordinary, had a way of playing that left critic Walter Nhlapo gasping, but in the end not even Toko's curious brilliance was found to be without black American precedent:

I can't explain this except if I were taught Psychiatry or practise it. It is wonderful how he pounds the piano. As time marches on, charmed by the strains of music, for it is said 'music hath its charms', he becomes hotter and hotter; bangs the instrument, leaves his stool, knees on the ground, plays with his back towards the piano, sits on the keyboard and plays with his haunches. Such playing is seen in Harlem. (BW, 19 October 1940)

But as the earlier references to the likes of Woody Herman and the Andrews Sisters suggest, the category of black American musicians was not entirely rigid in the minds of black South Africans: white Americans occasionally slipped in, perhaps because they were - rightly or wrongly - identified with the music made by the 'Africans in America'. Yet alongside the strong, emotive category of 'Africans in America', the performance culture of black South Africans posited another, looser category, filled with images of the stars and styles of Western - mainly American - popular culture. These too found their way into the practices of vaudeville and jazz, where they also served as examples to be copied, and as criteria of success. At least as early as 1930 the black press was carrying prominent advertisements in which lists of Zulu records on the Zonophone label nestled alongside those of 'Dixie Records' featuring performers such as Jimmy Rodgers, the Carter family, and the McCravy Brothers. The ubiquitous 'Waiting for a Train' featured prominently, and promised the ultimate in identification: 'You can feel like Jimmy Rodgers himself!' (ILN, 25 July 1930; UWB, 22 November 1930). That was a thrill which thousands sought, as Es'kia Mphahlele recalls in his autobiography: 'At Christmas-time Jeemee Roe-Jars (Jimmy Rodgers), then in fashion, yodelled plaintively from various parts of the village' (Mphahlele 1959, p. 22). By the late thirties, individuals and groups vied for comparison with selected white American models. The Kimberley Amateur Entertainers boasted a tap-dancer whom they called 'our Ginger Rogers', while De Pitch Black Follies of 1938 - giving themselves a yearly identification tag after the manner of, say, the Ziegfield Follies - offered audiences a special treat in the shape of little Doris Shuping, 'the copper-coloured Shirley Temple'. Not to be outdone, the Masinya Kids proffered not one, but an entire troupe of " "darkie" Shirley Temples'. Still more exotically, and revealing the extent of the saturation with images derived from American movies, by 1941 the Follies were including scenes with names like 'Hawaii Calls', which 'took the "house" to those fabulous islands of the South Seas' (UWB, 9 July, 20 August 1938; BW, 19 March 1939, 1 November 1941).

By the time the Concert and Dance exploded among urban blacks in South Africa, the American connection already had a long history. The missionary presence, cultural and educational contacts, and economic interests were the main conduits which transmitted American examples and through which they were sought. A practice of special importance was the minstrel show which, in South Africa as in the USA, was one of the most important forebears of vaudeville. And minstrel shows were introduced into South Africa surprisingly early: the Christy 
Minstrels disembarked in Cape Town in 1862, another American minstrel troupe landed in Durban in 1865, and black-face minstrelsy quickly became massively popular among white South African audiences. Blacks were exposed to the genre from the start; by 1880 , at least one African minstrel troupe was performing in Durban. ${ }^{4}$ In the end, however, as far as jazz and vaudeville were concerned, the most immediately significant repositories were the printed sheets of ragtime songs - often indistinguishable from 'coon' songs, as minstrel songs were called in their final stage - other Tin Pan Alley songs, phonograph recordings and, later, films and published jazz arrangements. Some of these were available long before the Concert and Dance institution absorbed them and turned them to its own ends: by 1904, for instance, recordings and tonic sol-fa versions of ragtime or 'coon' songs were not only being sold in trade stores, but songs of this kind were also being performed by black choral groups (Coplan 1980, p. 164 and 1982, p. 371). And when, by the 1920s, the gramophone had installed itself as a common feature in the homes of blacks living in the cities, access to American performance culture (even if this culture was sometimes mediated via England) increased dramatically (Couzens 1985, p. 67).

Vaudeville artist Tommy ('China') Beusen was not yet in his teens when he began buying records with the money he had earned as a caddie for white golfers in the mid-1920s. By the time he joined the Africans' Own Entertainers in 1929 at the age of fifteen - a group that was then newly formed but would go on to great fame - he already had a considerable repertoire of songs, learned from recordings: numbers sung for example by Layton and Johnstone, or Bing Crosby, or popularised by Jack Hylton's Band. The youthful Entertainers were also to extend their repertoire and hone their craft by copying recordings. 'China' remembers the status attached to any owner of a sizeable record collection:

We were very, very, very fond of buying records. You could go anywhere you like in a location - there's always records. Some people play them in the yard, you know, under the grapevine. Sit there and play with their records. Boasting! You know, it's like it is now: everybody wants to buy a posh house, well furnished, and a shining Mercedes there. Ja, okay, you look at those things. When you start working and you try your best, you want to buy yourself a Mercedes too, or a house. But then it was the records! Everybody wanted... Ooh, I've heard that record! Man, I'm going to buy that record! (Beusen 1986)

When local jazz musicians also bought and copied the records, they were unwittingly doing exactly what their American heroes traditionally had done. In Davenport, Iowa, in 1918, Bix Beiderbecke had a gramophone and used it to memorise solos by Nick La Rocca (Tirro 1979, p. 205); in Johannesburg in the early forties, future bandleader Ntemi Piliso listened to recordings and tried to play exactly like Johnny Hodges (Piliso 1985).

For those who could read, there was also the other option. In fact, for a bandleader like Peter Rezant - always proud of the reading skills of his Merry Blackbirds - it was better to hear the recorded version after the band had mastered the piece from the printed orchestration. And Edward Sililo, who was the first to play trumpet with the Jazz Maniacs, remembers that in 1929 the fledgling Maniacs often learnt American and English jazz and dance pieces from what he calls the imported 'piano leaflets' or 'vocal scores' (Sililo 1986). Similarly, Pitch Black Follies star Lindi Makhanya's early and formative encounters with ragtime and vaudeville music took place when her Aunt Elda brought printed songs to Lindi's home and sang them, accompanying herself on the 'baby grand'. Despite her father's stern 
objections to 'that type of thing', Lindi learnt several songs in this way. One was Irving Berlin's 'All Alone' (Makhanya 1987). Thus a song by one of the most gifted composers for the contemporary American vaudeville stage, written for Broadway in or around 1921, was sung about three years later by an eight-year-old African girl in the suburb of Sophiatown in western Johannesburg.

Films were watched by black South Africans long before the invention of the sound movie in the late twenties. In 1924 Sol Plaatje, writer and political spokesperson, brought back films from the United States which he screened in various parts of the country. But even prior to this, American missionary Ray Phillips had been using films as a method of social control in mine compounds (Couzens 1985, p. 292) - a precedent broadly adopted by such institutions as the BMSC, whose 1926 annual report mentioned the screening of 'special feature bioscope pictures', among other things, to show that it was 'playing an active part in shaping Native leisure-time activities, moulding Native character, and enlarging Native outlook' ${ }^{5}$ By the thirties, a number of commercial cinemas for blacks were in existence: Johannesburg, for example, had the Goldberg, West End, Good Hope, Osrins, Star, new Palace Theatre and others (BW, 15 February 1936, 3 June 1939); and most of the black townships showed free films, out of doors, even on cold winter nights. Despite controls and strict censorship, the movies had an impact which it is difficult to overestimate. For jazz and vaudeville artists, films were an apparently infinite source of things to be emulated or developed: ideas, melodies, songs, routines, dance steps, styles of presentation, ways of dressing, ways of playing; and of course they also provided ways of estimating local achievement. Lindi Makhanya remembers that Johannes 'Koppie' Masoleng - formerly with the illustrious Darktown Strutters, but by the late thirties a member and the coach of the Pitch Black Follies - used to encourage the Follies cast to see the Hollywood musicals:

He liked us to go to musical shows. Ja, all musical shows. We'd go there - he'd take the cast, you know. To get an idea, you see, how we must perform. He used to like us to go a lot to Ginger Rogers' and Fred Astaire's shows. You see? To get the style of Fred Astaire and Ginger Rogers, you know. (Makhanya 1987)

Some, like Walter Nhlapo, felt that the troupes should pay even more careful attention to the Hollywood musical. 'Why can't troupes present different items like film studios?', he asked. 'For instance, 20th Century Fox's 'Rose of Washington Square" can never be either like R.K.O.'s "Dance Girl, Dance" or Metro-GoldwynMayer's "New Moon"' (BW, 28 December 1940). But for top bands like the Merry Blackbirds and their audiences, the musicals were the ultimate, and stunning, confirmation. When he thinks back to the reception of his band after the impact made by such films as Sun Valley Serenade and Orchestra Wives - both featuring the Glen Miller band - Peter Rezant's excitement and pride is even today as fresh as it must have been in the early forties:

Oh my God, these fellows [in the Merry Blackbirds] were very, very able, very, very able! When this picture of Glen Miller came out, where the band played 'Chattanooga-ChooChoo', we were right on top of the mountain at that time. Right on top! When that music came out, we played it - 'Blue Serenade' and all those serenades and so forth. But 'Chattanooga' was the big number, and 'In the Mood' was the big ... those were there the big numbers. So when the crowds would hear that, after the picture had been shown, oh, they would go mad, mad, mad, mad, mad! The police couldn't stop them away from the doors in the places outside Johannesburg where we would go to, when they hear that sound. They they relate the sound to the picture now. (Rezant 1985) 
And at exactly the same moment, one of these very same films (Orchestra Wives) was providing fundamental inspiration for a young pennywhistle player, not yet out of his teens, who was to develop into one of the most important composers and bandleaders of the fifties - Ntemi Piliso:

What actually inspired me was the demonstrations by the trombones, you know when they -. So I thought, That's wonderful - I think I, I'd like to do the same thing! Unfortunately I couldn't get the trombone. Ah, so this chap had a clarinet for me. I said, Well as long as it's an instrument - because I want to play an instrument! I took up the clarinet and started from scratch. (Piliso 1984)

Within the discourse supportive of Concert and Dance, and of its infatuation with black American models, two of the imported genres stand out as having been given special attention: spirituals and, not surprisingly, jazz itself. Like the minstrel show, the spiritual was one of the major contributions of American music to South African music in the nineteenth century. Visiting black American jubilee singers, in keeping with contemporary trends in black minstrelsy in the USA, included spirituals in the programmes they sang around the country, and thus left a legacy that reverberated deeply in the consciousness of Africans. The first jubilee groups visited in 1890; they were the Hampton Jubilee Singers and Orpheus McAdoo and the Virginia Jubilee Singers, and by the end of the decade they had between them returned several times and made numerous tours. The mission churches (especially the African Methodist Episcopal Church) continued the process of popularising the spiritual; in a different way, so did the separatist churches. Enoch Mgijima's millennarian Israelite movement, for instance, 'used a hymn book blending Xhosa words and melody with spirituals taught them by Black American Baptist missionaries of the Church of God and Saints of Christ' (Coplan 1982, p. 371). Given this recent history, it is not surprising that urban Africans infatuated with black America should have built spirituals into their vaudeville stagepractices, and - from the beginning - accorded them a special place; nor that Reuben Caluza, the universally loved composer and choirmaster, on his way home from a period of study in the USA, should - as late as 1936 - have declared that he had studied 'Negro Spirituals' during his stay and announced that he hoped 'to be able to spread the knowledge of them in South Africa' (BW, 21 March 1936). In short, all Africans associated with vaudeville would have agreed with the critic for Ilanga Lase Natal who, in 1923, asserted that through spirituals

there breathes hope and faith in the ultimate justice and brotherhood of man. The cadences of sorrow invariably turn to joy, and the message is ever manifest that . . . every man will be free. (ILN, 2 November 1923)

And for this reason, many would have argued, spirituals are 'doubtless ... the finest pure music which has yet come out of America' (UWB, 29 October 1932).

About what exactly ' $j a z z^{\prime}$ ' was, there was - initially at least - less clarity. Certainly it was one of the topics of the day. "The great popularity which "Jazz" music has attained in this country and in Europe', an editorial in Ilanga reflected in 1920, 'has caused a great deal of discussion to arise concerning its origin' (ILN, 3 September 1920). Those origins soon seemed clear: and when they did, it was held to be 'unquestionable' that this music which had spread 'like a flame throughout the world' had its roots in 'the Africans' strong sense of rhythm'. Jazz, one letterwriter eventually insisted, was 'a modified and cultured form of our old Bantu music or dance, and ... sensible people will keep pace with the changing times' 
(UWB, 29 October 1932, 22 July 1939). Thus the terms of the discourse in which jazz was self-consciously accommodated, were the familiar ones of identity-indifference: jazz had been developed in distant parts of the world, but its developers - even though they might have been unaware of it - were in essence Africans ('Africans in America') who, under the impress of changed social and economic conditions, had transmuted their ancient cultural heritage and made it relevant to new circumstances. It was a compelling argument for doing likewise.

\section{III}

American - and primarily black American - culture provided the greatest source for the Concert and Dance repertoire. But at the same time - and surely more significantly for the development of an authentic South African jazz - the troupes and the bands made use of styles and elements whose origins lay on their very doorstep. The most obvious of these were various types of traditional music, which reached the Concert and Dance stages of the cities more explicitly in the work of the vaudeville companies than of the bands. This is paradoxical: it was after all these very troupes that, like the bands, were aspiring to emulate what they held to be the most sophisticated foreign acts. Certainly the format of these vaudeville programmes - with their encapsulated scenes, their roots in minstrel shows, their affinity to variety concerts - readily lent itself to the incorporation of the most disparate items; but this does not in itself explain why materials of traditional provenance should have been incorporated, even if usually on a limited scale, in the form of songs, dances, and 'scenes from traditional life.'

So why should the need to include such materials have arisen in the first place? On the evidence available, three related reasons seem to suggest themselves. First, traditional music was seen as a rich and important heritage and therefore one that deserved to be preserved. Such a view was already widely held at least among the educated petty bourgeoisie - by the time the elite South African Bantu Board of Music announced, in 1931, that one of its constitutional aims was 'to undertake research work into Bantu Music, and to collect for preservation, folksongs in their original form' (Imvo Zabantusundu, 17 March 1931). This 'folk music', one of its most articulate defenders, the university-educated critic Mark Radebe, ${ }^{6}$ wrote around the same time, 'is our most treasured cultural inheritance'. What made it important, he suggested, was that these songs 'are intimately associated with Bantu history and lie very near the heart of the people. In this music there is a mass of characteristic material' ( $B W, 21$ October 1933; UWB, 9 July 1932). Never wanting for influential spokespersons, this viewpoint also enjoyed support from no less a figure than Reuben Caluza. Placed in charge of music at Adams College in 1936, he is reported to have said that his principal aim in the job would be 'the preservation of Bantu traditional music'; and that he hoped 'to make a collection of old instruments and to form something like a folk dance society which will use purely African percussion, reed and string instruments' ( $B W, 21$ March 1936).

The second reason followed from the first: since this traditional heritage was so rich in significance, if it was kept alive it could lead to exciting creative possibilities in the present. 'The African musician and harmonist has his chance therefore', wrote the editors of Umteteli in 1933; 'the world is waiting' (UWB, 11 November 1933). But it was Mark Radebe who expressed the drift of this argument most 
profoundly. For 'music to be truly national', he wrote in an article devoted to the topic, 'it must be based on the idiom of the people. Those most valuable achievements in musical history have been essentially national in spirit'. Thus if 'a distinctive Bantu music' were to emerge, it would have to be based on what he called 'the only real Bantu music, namely, its folk music'. If this occured, it could be the foundation for 'a golden age of national Art' (Radebe 1932).

The third reason also followed from the first, but to a somewhat different end. The traditional heritage needed to be preserved, not simply because it was rich in significance or because it could nourish and enliven creative enterprise, but for the sake of those not yet born who would otherwise know nothing about their roots. Daniel Marivate, singer, composer and teacher, captured the spirit of this view in a letter written in 1935:

We are passing at an age when things purely African are being replaced by things European. We who are between, that is, partly brought up against Native Background and partly peeping into European life and culture have great responsibility for our race. We may either allow all native life, art, music, language to be crushed and wiped out or preserve all the present ideas, customs, life, music and art for those that will be born at the time when there will be not uncivilised Bantu ... I think the black man of the future will want to know what kind of people his ancestors were and what kind of life they were leading and to be able to satisfy himself that he has really got a peep at the life of the old Bantu he must read the ideas that actually came from his Bantu predecessors.

There was undoubtedly also a fourth reason, the basis of which has been sketched earlier. Though largely under the control of upwardly aspirant, mission-educated blacks who constituted what has been called a 'repressed elite', the Concert and Dance institution catered to blacks of widely differing social, economic and educational backgrounds. A great many of these people would still have retained meaningful links with rural communities - and therefore with varieties of traditional music. More important, all of them would have found themselves thrown together in urban ghettos, confronting similar problems, and having to deal with the same spectre of racial capitalism. Out of this common experience of racial and economic oppression, blacks in the towns developed cultural practices which frequently expressed this commonality, tried to accommodate differences of background and interest, and thus often attempted to transcend some of the incipient contradictions of social class.

If traditional materials appeared in the repertoire of the vaudeville companies in fairly explicit fashion, it was left to the bands to make use of these elements in more mediated form. What the bands did - side by side with their appropriation of dance music from abroad - was to assimilate the musical styles that had been developing in South Africa's slums and ghettos since at least the First World War, and that (despite certain regional differences) appear to have fallen generically under the term marabi. In recent years, a considerable amount has been written about marabi - some of it not free of sheer conjecture or even mythology. While part of this work has been useful, occasionally even pioneering, our knowledge of marabi is still inadequate, both in its details and in its foundations: for this to be remedied, rigorous and painstaking research will be necessary. For our present purposes, what is essential to our understanding of marabi as the prehistory of South African jazz, is that (in the words of jazzman and journalist Todd Matshikiza) it was "the name given to the "hot", highly rhythmic repetitive singlethemed dance tunes' of the period from the teens to the early thirties; and that 
these tunes 'were largely the illiterate improvisations of the musicians of the day' (Matshikiza 1951). Essentially, marabi was the music of a variety of secular social occasions, which usually had in common not only the activity of dancing but also that of consuming alcohol. Perhaps the most famous of its venues were the shebeens (the illegal backroom or backyard liquor dens, where various kinds of homebrew were sold), and the weekend-long slumyard parties. Since it was an original style generated in and by the ghetto, the claim that it was, more than any other style, the music of the ghetto, is probably not unfounded. It was also primarily a keyboard, banjo or guitar style based on a cyclic harmonic pattern, much as the blues was: the basic marabi cycle, however, may be said to have stretched over four measures, with one measure for each of the following chords: I - IV - I $6 / 4-V$. The cyclical nature of this style clearly derives from traditional sources: in traditional African musics, repeating 'harmonic' patterns (sometimes called 'root progressions' or 'harmonic segments') are fundamental. Indeed, as ethnomusicologist Gerhard Kubik has pointed out, cyclicity has also become 'an important basis of nearly all neo-traditional music in sub-Saharan Africa' (Kubik 1974). These cycles in neotraditional music he names 'ostinato harmonic patterns', and argues that they give rise to 'short forms' (as opposed to song forms) - clearly another annotation for what Matshikiza had described as 'repetitive single-themed' tunes. Thus from a structural and harmonic point of view, marabi is properly to be understood as a form of neo-traditional music.

The melodies superimposed on these endlessly repeating patterns sometimes became legendary; sometimes lyrics were invented as well, and in some instances these contained political commentary or protest. A significant proportion of these melodies appear also to have been traceable to traditional origins. Edward Sililo, who in the 1920s played marabi piano at Ma Jeremiah's shebeen in the slum area of Doornfontein, in Johannesburg, identifies this corpus of melodies as 'a mixture of Sotho music, Xhosa music, Zulu music' - or more specifically, as a mixture of their ceremonial songs. But that was not all: frequently the tunes would be drawn from a familiar stock of African Christian hymns. In such a case, 'we'd just take a separate portion of the [hymn tune] and then jazz it up - dance that music!' (Sililo 1986). ${ }^{8}$ Yet another source of melodies were the commercially popular tunes of the day:

You see, ahh, for instance they would have a song like, in the early twenties there were songs like '(Oh) Yes, We Have No Bananas'. And we'd take a snatch from that and put it in the marabi. And I play - any tune I play: now anything I remember I play it same time. As it just crosses my mind I play it, but I keep the same rhythm all the way. (Sililo 1986)

This, then, was the manner: cyclical repetitions of one melody or melodic fragment, yielding eventually, perhaps, to a similar treatment of another melody or fragment, and perhaps then still others, each melody possibly from a different source. And in this manner 'you played with no stop - you could play for an hour and a half without stopping' (Sililo 1986). Throughout, a rhythmic accompaniment would be provided by a player shaking a tin filled with small stones. One standard pattern, as demonstrated by Sililo, is among the most basic and widespread drum patterns of traditional Nguni music:

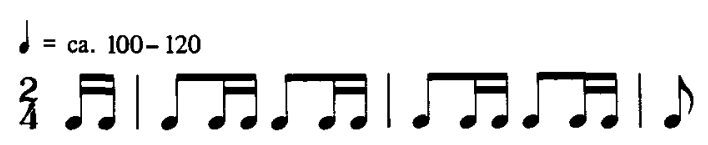


Other styles also left their mark on the melodic and rhythmic structures of marabi: types of 'coloured'-Afrikaans and white-Afrikaans dance music known as tikkie-draai and vastrap, as well as the ghommaliedjies of the Cape Malays. There appear also to have been varieties of marabi associated almost exclusively with certain groups of Xhosa- and Zulu-speakers. The Xhosa version - reputedly less polished than mainstream marabi (Dan Twala, quoted in Coplan 1980, p. 210) - was named tula $n^{\prime}$ divile, after the words of a song first made popular by migrant workers in Durban in the late 1920s (Erlmann 1987, p. 39); the Zulu version - really a kind of 'concert and marabi dance' developed by Zulu migrant workers in Johannesburg - was termed ndunduma, after the Zulu word for the minedumps that seemed to them to symbolise that city (Coplan 1980, p. 233). Marabi and its close relatives, together with the vital, hedonistic subculture that supported them, have long disappeared. In their original form, none of these styles was ever recorded or, in their day, even written about - except in the most cursory and disdainful fashion. What little we know we owe to those who, long after the event, had something they were able to remember, and committed a recollection to paper, or lived until a much later time when historians were interested in recording their oral testimony. Thus, for instance, about twenty years after the waning of the marabi era, the remarkable poet, playwright and journalist Herbert Dhlomo left a richly evocative reminiscence of ndunduma - his 'educated' prejudices notwithstanding:

Ndunduma concerts were real refuse dump affairs, musically and morally. They were attended by degenerate young elements, the uninitiated newly-arrived country bumpkins and the morbidly curious. The people danced to the accompaniment of an organ and most cacophonic 'orchestra' of small tins filled with pebbles. The atmosphere was obscene. For the first time in the history of Bantu entertainments liquor was introduced. The functions were like nightclubs of the lowest order.

And yet what naturally talented players the ragtime and the Ndunduma concerts had! Vampers (as they were called) who improvised many 'hot' original dance and singing numbers at the spur of the moment, and who play or accompany any piece after hearing the melody once, and did so in any key; fellows who played music not because it was fashionable, but because they were born musicians - helpless victims of a Muse that gave them fire which consumed them as they could not control it, nor knew nor cared what it was; men who, like tribal bards of old, created beauty they knew not and flung it back unrecorded to the elements which gave it birth. (ILN, 20 June 1953)

And nearly half a century after marabi's twilight years, Wilson 'King Force' Silgee, who began playing saxophone with the Jazz Maniacs in the mid-thirties and later led the band, recalled something of what it felt like to attend a marabi party:

Marabi: that was the environment! It was either organ but mostly piano. You get there, you pay your ten cents. You get your scale [share] of whatever concoction there is, then you dance. It used to start from Friday night right through Sunday evening. You get tired, you go home, go and sleep, come back again: bob a time, each time you get in. The piano and with the audience making a lot of noise. Trying to make some theme out of what is playing. (Silgee 1979b)

The association of marabi with illegality, police raids, sex and a desperately impoverished working class - large numbers of whom would at any one time have been unemployed - stigmatised it as evil and degrading in the eyes of those blacks whose notions of social advance rested on an espousal of Christian middle-class values. Yet, though both the bands and their audiences included members of this latter group in significant numbers, the heterogeneous nature of black ghetto society meant that there were also strong pressures towards the inclusion of marabi 
in the bands' repertoires. Edward Sililo remembers that in 1929, as a member of the fledgling Jazz Maniacs, the group used to play marabi tunes - either by ear, or (occasionally) in written-out arrangements. This practice continued long after the band expanded (Sililo 1986). Even band members who grew up in homes that deeply disapproved of marabi, knew the style and its tunes well. Many would be able to say with Silgee - who grew up in such a home but used to watch and listen to marabi 'at the window' - 'It got itself infiltrated in me' (Silgee 1986). Not even the prestigious Merry Blackbirds steered clear of marabi. Peter Rezant makes this point quite emphatically:

You couldn't avoid that at that time, you see. Everything had that twist into marabi. Because it was the marabi era... They were little ditties, you know, coming from the townships ditties as you hear them. And somebody would be suggesting who'd been toying around with them, and then ultimately we play them as we hear them. One playing the melody and the others would fit in and so forth. Well, the trumpet and the alto were always the lead instruments. Then, if the trumpet plays in front, then the alto should find itself the, ahm, the harmony, to harmonize - and so did the trombone. And the correction would come, to correct our harmonies, from the piano. That's how we began, you know, before the orchestrations came in. (Rezant 1985)

IV

To play orchestrations, band members - or at least some of them - needed to be able to read; to play 'township ditties', they 'only' needed to be able to play by ear. But to do either, the primary requirement was an ability to play the instruments. Where did they learn? An important part of the answer is suggested in the ironic reflection that in the early 1920s at least two future members of the Jazz Maniacs could regularly have been found sitting attentively in church. The one, young Wilson Silgee, would have been watching his father, a church minister, coach the brass band that accompanied the choir during Sunday services; the other, a slightly older Edward Sililo, would have been holding a trumpet and doing his best to play along in a similar band, conducted by one Joseph Mmutle in the Wesleyan Church in Western Native Township (Silgee 1979a; Sililo 1986). In short, the most important preliminary training ground for dance-band musicians were the missions: their stations and schools, and the brass (and other) bands attached to them, as well as the Salvation Army. (For vaudeville entertainers, the mission school and church choirs, together with their school concerts, played an equally formative role) (see Figure 5).

It was the British and German missionaries who had first introduced brass bands into South Africa - for the glory of God, the advancement of 'civilisation', and the procurement of converts. The scale of this musical intervention was inpressive, and before the end of the nineteenth century mission stations in every province had brass bands with which to buttress their appeal (Coplan 1979-80, pp. 589, and 1980, p. 186). Africans soon appropriated the idea for their own, rather different, purposes. The Tswana and the Pedi seem to have been the first to establish autonomous brass bands - doubtless partly because their own long tradition of pipe-ensemble performance provided a context which facilitated the adoption of the 'new' Western aerophones. The earliest of such bands appeared, wearing uniforms, in the Transvaal in the 1880s, sponsored by traditional chiefs to symbolise their cultural and political aspirations in the colonial situation (Coplan 1982, p. 368). As the black locations in the cities grew, and Africans found themselves increasingly herded together as proletarians, these brass bands began to lose 


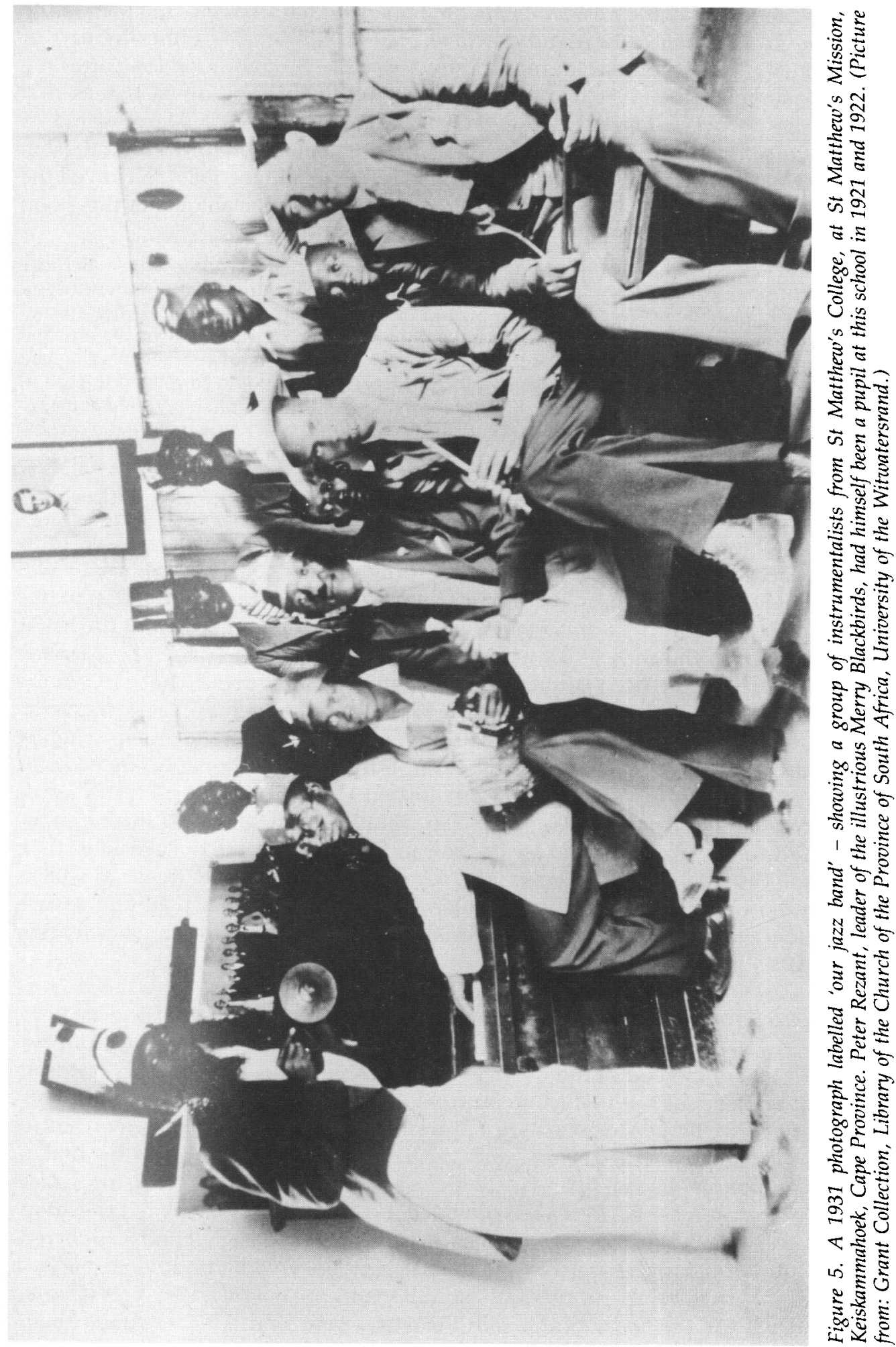


their separate tribal affiliations. Thus appeared, for instance, Modikwe's Band, named after its founder, who had received training in the Salvation Army Native Band in Johannesburg, but left to set up his own band in Rustenburg in 1911; and the Bloemfontein-based Mokgoro Band, founded by Jeremiah Nlatseng in 1908 and still going strong (indeed even touring) thirty years later (UWB, 5 November 1938). ${ }^{9}$ Significantly, some of the proletarian bands participated directly in early vaudeville entertainments. ${ }^{10}$

But whether these diverse groups now played ad hoc arrangements of traditional African melodies, or typical band music, or hymn-tune accompaniments for use in church, or even their own more secular versions of hymn tunes, did not essentially matter: what was important was that an institutional form (with striking similarities to the contemporaneous New Orleans marching bands!) was in place, and that it was to have profound implications for the growth of a dance- and jazzband tradition in South Africa. Or rather, the fact that these diverse bands played a diversity of musics mattered only in this positive sense: that the variety of musics produced and reproduced by the brass bands were the first steps toward the assimilation, by Africans, of a variety of styles within a Western instrumental tradition, and in ways later to be developed both within the Concert and Dance format and in the evolution of local jazz itself.

Nor did it matter, from this particular perspective, that the brass-band institution tended to be appropriated for differing ideological ends. The 'repressed elite' adopted it for the symbolism of its Christian, Eurocentric affiliations, and its usefulness as a means of social discipline; in these hands it was fostered by organisations such as the Transvaal African Eisteddfod in the early thirties. Whites, after the missionaries, also continued to establish black brass bands, and for not dissimilar reasons. The Witwatersrand Native Labour Association in the late thirties imported a white bandmaster to create and train a band to play to African workers on the gold mines, and, later, African brass bands were set up by the Native Military Corps as part of the war effort (UWB, 22 July, 18 November 1939, 3 February 1843). Towards the 'lower' end of the class spectrum, brass bands proliferated as well but served quite different goals, usually related broadly to community needs such as economic support and solidarity. Most common were the marching bands that drummed up support for the stokvels - informal 'savings societies', whose members held parties and contributed sums of money to each other, in rotation. ${ }^{11} \mathrm{~A}$ report in Bantu World in 1932 described one such band:

Gaudily attired men and women in uniform parade the Western Native Township on Sundays. The men are dressed in blue-serge military coats, sparkling with brass buttons, and white creped caps; while women dress in black skirts and white blouses. Forming rows, men at the van, and women at the rear, they march two abreast.

The Stockvell Band as it is called has drummers and trumpeters who play the music, while the rest sing. So appealing is their music that many crowds are attracted. This diverts many people in the township. (BW, 17 September 1932)

Many stokvels dealt in alcohol. Where this occurred, they became difficult to distinguish from the informal-sector, and illegal, drinking houses known as shebeens, run by women known as shebeen queens, or skokiaan queens (after the name of one of their potent brews). For such women, these drinking houses were normally their only source of income. Brass bands sometimes also marched to solicit clients for these institutions, providing occasions for disparagement by more 'respectable' location dwellers. A letter in Bantu World in 1937 exemplifies a typical outburst: 
As civilisation advances, backwardness, paganism is also busy creeping on to retard our steady progress. We were rather jubilant that Tulandivile and the like were almost dying out and yielding place to classical music. Now, instead of Musical Schools increasing, Brass Bands are forming up in the locations to play things worse than Tulandivile - to assist the Skokiaan Queens by canvassing for more customers. These Brass Bands roam from one location to another attracting some worthy people and children as they go. Such mobs are not only an obstruction to traffic, but really suicidal to the African public ...

Many children who have glittering opportunities to make good take such interest in these Bands that they grow a wish that they would be players of these Bands in future rather than be Pathfinder-masters. This sort of thing creates more Marabis. These children would have become learned men of eminence, made good for their country and their people. What suicide - as I say! (BW, 29 May 1937)

Yet from the point of view of the developing jazz tradition, such ideological contestation was less important than the existence of the brass band as an institutional form. On the one hand, a regular columnist in Bantu World, writing from Johannesburg's Eastern Township in 1941, could remark on 'the noises of brass bands turning hymns into jazz tunes ... in tents, rooms and under sackings all over the location' (BW, 18 January 1941). On the other hand, Umteteli in 1943 could interview Sergeant-Major C.W. Hall, formerly of the Royal North Lancashire Regiment but now training a Native Military Corps Brass Band, and report that

most of his musicians came to him 'raw'. Some of them still cannot read or write their names, but through his training they have learned to read orchestral scores. The sgt-major said that they spent five hours daily practising and had become so proficient that, if called upon to perform, they needed no rehearsing ... Pointing to his No. 1 trombone player, a smartly dressed Mosuto soldier, sgt-major Hall said that he mastered the trombone in six months ... 'My men play any march I put in front of them', he added ... In addition, sgtmajor Hall has organised a six-piece dance orchestra from among the same instrumentalists. (UWB, 13 February 1943) ${ }^{12}$

Alongside the plethora of brass bands, other forms of instrumental tuition also developed, some of them still linked to the work of the missions, some quite independent of it. Many musicians were basically self-taught, often with the aid of books called 'instrumental tutors' which could readily be purchased from music shops. This of course presupposed at least a smattering of formal schooling and an elementary level of literacy - certainly never to be taken for granted in a society in which school attendance for blacks was not compulsory, and in which poverty determined that black children try to earn a paltry income as soon as possible. When he wanted to learn the trumpet, Edward Sililo bought a 'Lawrence Wright' trumpet tutor and taught himself; Wilson Silgee, as an adult, learnt the saxophone in the same manner. With few exceptions, the private teachers were whites - but for most blacks their fees were 'prohibitive' (UWB, 18 March 1939). Despite these contradictions, the black press regaled its readers with the success stories of those few who - in ways it never adequately explained - had scaled the peaks of music education, in 'white' terms. An early favourite was one Reuben E. Davis. He was described as

a Native living at Maritzburg who has demonstrated that achievement can be surmounted when the will to do so is strong enough. Mr Davis has obtained the musical degree of ATCL - a success denoting both high courage and high ability. He is a Venda, the son of slave parents, and speaks Afrikaans and English but no Native language. He teaches music and five of his pupils recently passed the Trinity College examination. (UWB, 10 September 1932)

In such a context, it is a striking fact that many members of the top jazz bands and troupes of the thirties had had at least some tuition from white teachers - by 
private arrangement as well as through the mission schools - and continued to procure white tuition as the need arose. This tells us something about the mixed socio-economic background of these groups, and reminds us again of their complex class composition. Wilson Silgee of the Jazz Maniacs - a group often simplistically described as a marabi band - would, as a boy, not only have been found sitting in church while his father coached the congregation's brass band; he could also have been found, aged about ten, perched on a piano stool in the private studio of a Mrs Manson, a white teacher in Marshall Street, Johannesburg (Silgee 1979a). The lessons continued for a year; later, as a pupil at Adams College, he continued to study music. Jacob Moeketsi, the most famous of the Jazz Maniacs' pianists, not only had a mother who sang hymns in the family living room while his father accompanied her on the organ; he was also a boarder at Healdtown Institution where he took lessons in classical piano from a white lady teacher (Maile 1985; 'Kippie's Memories', Staffriders November 1981). It was perhaps this same woman who taught Sol Klaaste - vaudeville piano prodigy, boogie-woogie artist and, later, pianist for the Merry Blackbirds and numerous other groups - when he too attended Healdtown in the late thirties; but it must be said that by then he had already been taught privately by a Miss Brenner, ATCL, a Mr A. H. Ashworth, Mus. Bac., and others (BW, 1 August 1936). Two of the first women in South African jazz - Hope Khumalo, among the earliest of the Jazz Maniacs' pianists, and Marjorie Pretorius, the first vocalist with the Jazz Maniacs and with the Merry Blackbirds - had both studied classical piano with a Mr Goldberg, a white teacher in Doornfontein, Johannesburg. Though initially self-taught, Peter Rezant of the Merry Blackbirds went on to find a German violin teacher in Johannesburg, and then took saxophone lessons from a certain George Louter who played in a (white) band of the South African Railways. Rezant remembers that one of the members of the Blackbirds had studied music at Adams College, while another had acquired 'advanced' theoretical knowledge from a German music teacher in Rustenburg (Rezant 1974, 1984). Phillip Mbanjwa, trombonist with the Blackbirds, publicly stated in January 1934 that the band had 'a distinguished European teacher who gives them lessons every week' (BW, 27 January 1934). ${ }^{13}$ (In the mid-thirties the Jazz Maniacs also enjoyed 'the guidance of a European friend once in a while' (UWB 18 March 1939).) Thus do the examples proliferate.

A similar picture emerges from a close look at the vaudeville companies. Highlights here might include the efforts made by Johanna Phahlane, the versatile and brilliant founder and leader of the (all-female) Merry Makers of Bloemfontein. Writing about the preparations for what was probably the group's first Transvaal tour in 1935, she recalled that she had

made all arrangements to have training courses in the National-Theatrical movements at the Bloemfontein Grand Hotel Plaza with the able assistance of Miss M. Easton and Lady Eileen Burchmore so as to be fit for Johannesburg and other towns on behalf of my own Bantu people. (BW, 15 February 1936)

Getting ready to tour with a newly reorganised troupe in 1937, she again arranged for 'private lessons'. These included 'classes in music by Miss Joyce Mayhew of the Grand Theatre Hall and by Miss Grinter of Eason's Pupil Dancing School' (UWB, 11 December 1937). Another instance would be De Pitch Black Follies. This troupe included performers who had studied their craft with white teachers (musician and conjurer Victor Mkize had been a pupil at Dauby's School of Magic in Cape Town, and Griffiths Motsieloa had studied elocution in England (BW, 5 November 1938)), 
but their stage education - at the hands of whites - did not end there. The company was famous for its dance and tap routines, among other features; these were devised largely by Johannes 'Koppie' Masoleng who, according to former member Lindi Makhanya, periodically took advanced lessons from white tap-dance teachers, and passed on what he had learnt to the Follies cast (Makhanya 1987). And after the spate of early-forties films featuring Carmen Miranda ${ }^{14}$ had boosted the popularity of Latin-American music among black South African audiences, Motsieloa approached a (white) South African professional ballroom champion by the name of Teddy van Rensburg to coach three men and three women of the Follies cast in Latin American steps. 'They did very well with that', Peter Rezant remembers (Rezant 1985).

In many respects the Concert and Dance tradition was shaped by, and evolved in response to, the experience of racial and class oppression. The irony of the matter is that many of the skills that this dynamically growing tradition was creatively shaping for its own use, and that blacks were energetically seeking to acquire, were skills that were already 'owned', and could therefore be sold, on their own terms, by whites. Established black teachers of music (or of the other performing arts) were virtually non-existent. From about the mid-thirties, a tiny handful of black teachers of note began to appear: among them were Reuben Caluza, who took up his music post at Adams College on his return from the USA in 1936; Merry Blackbirds pianist Mrs Emily Motsieloa, who was running a piano studio in Alexandra Township by 1937 (and possibly earlier); and Mrs Marie Dube, Americanborn wife of Frederick Dube (the nephew of former African National Congress president, John Dube), who opened a small music school at the Methodist Institute in Grey Street, Durban, in 1938 (ILN, 30 May 1936; UWB, 3 April 1937; BW, 21 May 1938). ${ }^{15}$ But perhaps none realised the importance of the black challenge to white educational hegemony as forcefully as Wilfred Sentso, founder and leader of the Synco Fans troupe, and a jazz pianist and composer of some stature. As early as 1930 - at that time a teacher at Wilberforce Normal Department, and struggling for recognition as a composer - he wrote to Dr A. B. Xuma, then a Johannesburg medical practitioner but later to become president of the ANC:

My aim as a boy has also been to develop the theatrical music of our people as a profession besides my interest in the educational development of my people ... I would realise my dreams of a scientifically organised education of our Bantu people as well in Music. ${ }^{16}$

He had been a successful conductor of the famous Wilberforce Institute Singers and had for some years held the position of head of department when, in 1937, he resigned and moved to Johannesburg to set up his own school of performing arts ( $B W, 29$ January 1938). What he was really thinking about, as Todd Matshikiza wrote many years later, was the idea of

forming the biggest academy of jazz music for non-Whites in South Africa . . He had no accommodation and no instruments. He had no money to buy either. All he had was the enthusiasm of a fire-cracker. (Drum, June 1953)

He set up a temporary 'school' in the Bantu Sports Club, with branches in Alexandra Township, Orlando and Pimville, and distributed circulars offering tuition in piano syncopation, voice culture, tap-dancing, typewriting and music theory ( $B W$ 29 January 1938). By June 1938 he had found new, and permanent, premises at Mooki Memorial College in Orlando; according to the printed letterheads, this was the headquarters of 'The Wilfred Sentso Schools of Modern Piano Syncopation'. ${ }^{17}$ 
Within a year the institution had built up a reputation for teaching 'classical music, jazz syncopation, saxophone and trumpet blowing'; soon 'crooning, tap dancing and ragging' were to be added to this list, as was the existence of 'a fine troupe of young artists' (UWB, 18 March 1939, 27 January 1940).

The contribution of Sentso and his assistants to Concert and Dance subculture was remarkable. Indeed, five years after the school began, Bantu World ran a report which summarised its achievements:

This month June the Synco Schools will be five years old, and in those five years it has produced outstanding artists found in nearly every musical organisation in the Reef. Names like Mad-Joe (Broadway Stars), Marjorie Pretorius (Merry Blackbirds), Edward Manyosi (Minstrels), Jubilation, Emily Kwenane (Jazz Maniacs) etc., and instrumentalists like Maurice Sabi (African Rhythmers), Sherwood [Mackay] Davashe (Merry Mischiefs), Henry Mienaar, Sandy Ngamza etc., African Hellenics etc. are all names to be found in the schools' registers ... [Besides these, there are also the] Synco Fans Troupe and the Synco Beats Band, which have performed in European Night Clubs, theatres, halls, open-air Stadiums etc., the largest show of which was sponsored by the West Rand Consolidated Mines where a crowd of over six thousand people attended for a one night's concert. The schools have also pioneered and published popular music by publishing well known popular tunes like 'Boon-Town', 'Lady Mine', 'Tsaba-Baby-Tsaba' etc.

To commemorate this fifth anniversary a play entitled 'Five Years Service', script, music and all by Wilfred Sentso, will be staged in the Orlando Communal Hall ... [The] Synco Fans Troupe and Synco Beats Band will be used in the cast. (BW, 19 June 1943)

Sentso's performing arts school was a model, but one that would not be emulated for a long time. The fact that it existed at all was due not simply to Sentso's 'fire-cracker' enthusiasm, but to the beginnings of an important change in South Africa's social and political climate. These beginnings bore, during the ensuing decade, militant consequences that could scarcely have been foreseen by Sentso or any of his colleagues. And they carried implications of considerable importance for the Concert and Dance tradition itself. This, however, takes us beyond the frame of the present article, and must - like much else that could not be considered here - await another occasion.

\section{V: Conclusion}

If the Concert and Dance institution was the crucible in which the black South African jazz tradition was forged between the twenties and the early forties, the elements being drawn into that crucible were diverse and even contradictory; and the proportions in which they were invoked, like the relationships between them, were unstable and changing. At one moment, these elements reflected the cultural legacy of colonialism and the growth of racial capitalism visited upon black South Africans - as well as the durability of aspects of traditional culture which survived in rapidly changing circumstances. Yet, at another moment, these elements reflected not so much the way the African working class suffered the colonial legacy as its efforts to creatively appropriate it - while at the same time incorporating elements of traditional culture as a source of resistance drawn from the shared history. In this struggle between the cultural hegemony of the oppressor and the counterhegemony of the oppressed, a dynamic, and ultimately brilliant, new jazz was born. ${ }^{18}$ 


\section{Endnotes}

1 Many old performers stress this interdependence. The close connection between one of the top dance bands (the Merry Blackbirds) and one of the top vaudeville troupes (De Pitch Black Follies), for instance, has been pointed out by Marjorie Pretorius, among others. Starting around 1940, she was the Blackbirds' first vocalist - but they regularly shared the bill with the Follies, and then Marjorie (as well as instrumentalists from the band) would often appear as vaudeville artists in the Follies' shows. Or the band would provide instrumental backing. 'We were one thing with the Pitch Black Follies', she says. A year or two before she joined the Blackbirds, Marjorie had been vocalist with the Jazz Maniacs (also their first); and at that time she and two other women belonged to a small troupe called the Harlem Babies, who frequently appeared in the 'Concert' when the Maniacs provided music for the 'Dance'. Their routines, directed by comedian Petrus Qwabe, included singing, dancing and acting, and the Jazz Maniacs used to background us' (Pretorius 1987).

2 The author ('Musica') is very likely Mark Radebe. 'Musica' is, in any case, probably an early version of 'Musicus', a pen-name Radebe was using regularly by 1932 .

3 Paul Dunbar is the odd-man-out in this list: he was not an instrumentalist at all, but a poet and lyricist!

4 For a fuller treatment of the early history of the minstrel show in South Africa, see Erlmann (1986).

5 BMSC Annual Report, 1926 (AD843/B73.1: Department of Historical Papers, University of the Witwatersrand Library).

6 The claim that Mark Radebe was university educated is made by Herbert Dhlomo (ILN, 16 August 1952). Indeed, Dhlomo says that Radebe was one of Professor P.R. Kirby's first African students at the University of the Witwatersrand Libary.

7 Letter to J.D. Rheinallt Jones, 4 November 1935 (AD843/B47: Department of Historical Papers, University of the Witwatersrand Library).
8 Sililo cites the traditional Zulu ceremonial song, 'Entabeni siyagibela, entabeni siyehla', and the Christian Zulu hymn, 'Amagugu', as examples of traditional and Christian tunes that were adopted - and adapted - by marabi keyboard players.

9 For more on Modikwe's Band, see Coplan (1980, p. 191).

10 Jeremiah Nlatseng's Mokgoro Band, for instance, played in such an entertainment in the Community Hall, Batho Location, Bloemfontein, in July 1923 (UWB, 21 July 1923).

11 For a fuller discussion of the stokvel, see for instance Hellmann (1948, pp. 43ff).

12 Modikwe's Band - mentioned earlier - was one of the most famous of the brass bands; the Merry Blackbirds were one of the most famous of the dance bands. An anecdote that vividly illustrates the general point at issue here is the fact that among the saxophone players of the Merry Blackbirds sat one Mac Modikwe - son of none other than the founder and director of Modikwe's Band. Mac had learnt to play his first instrument, the French horn, as a member of his father's independent proletarian brass band (Peter Rezant, verbal communication, 17 February 1988).

13 For their appearance at the British Empire Exhibition in Johannesburg in 1936, the Merry Blackbirds were coached by English dance band leader, Teddy Joyce, who had been brought out with his band to play at the Exhibition (Rezant 1984)

14 Among the earliest of these were Down Argentine Way (1940), That Night in Rio (1941), Weedend in Havana (1941), and Springtime in the Rockies (1942).

15 See also Phillips (n.d., pp. 298-9).

16 A.B. Xuma Papers (AD843: Department of Historical Papers, University of the Witwatersrand Library).

17 Ibid

18 The contribution of the Human Sciences Research Council towards the funding of this research is acknowledged.

\section{References}

Beusen, Tommy. 1986. Author's interview, London, 28 April

Bozzoli, Belinda (ed.). 1983. Town and Countryside in the Transvaal (Johannesburg)

Coplan, David. 1979-80. 'Marabi culture: continuity and transformation in African music', African Urban Studies, 6, Winter

1980. The Urbanization of African Performing Arts in South Africa, Ph.D. dissertation, Indiana University 
1982. 'The emergence of African working-class culture', in Industrialisation and Social Change in South Africa, ed. Shula Marks and Richard Rathbone (London)

Couzens, Tim. 1979. 'Nobody's baby: Modikwe Dikobe and Alexandra 1942-6', in Labour, Townships and Protest, ed. Belinda Bozzoli (Johannesburg)

1985. The New African: A Study of the Life and Work of H.I.E. Dhlomo (Johannesburg)

Erlmann, Veit. 1986. 'A feeling of prejudice: Orpheus McAdoo and the Jubilee singers in South Africa, 1890-1898', paper given at the African Studies Institute of the University of the Witwatersrand, 25 August

1987. 'African popular music in Durban, 1913-1939', unpublished manuscript

Hellmann, Ellen. 1948. Rooiyard: A Sociological Survey of an Urban Native Slumyard (Cape Town)

Kubik, Gerhard. 1974. The Kachamba Brother's Band: A Study of Neo-traditional Music in Malawi, Zambian Papers (University of Zambia)

Maile, Sam. 1985. Author's interview, Johannesburg, 28 September

Makhanya, Lindi. 1987. Author's interview (with Veit Erlmann), Soweto, 13 February

Marks, Shula and Rathbone, Richard (eds). 1982. Industrialisation and Social Change in South Africa (London)

Matshikiza, Todd. 1951. 'Twenty years of jazz', Drum, December

Mphahlele, Es'kia. 1959. Down Second Avenue (London)

Phillips, Ray. n.d. The Bantu in the City (Lovedale, South Africa)

Piliso, Ntemi. 1984. Author's interview, Johannesburg, 24 January

1985. Author's interview, Johannesburg, 26 July

Pretorius, Marjorie. 1987. Author's interview, Johannesburg, 18 October

Quaker, Dale. 1986. Author's interview, Johannesburg, 10 October

Radebe, Mark, 1932. 'Bantu national music', UWB, 9 July

Rezant, Peter. 1974. Interview by Tim Couzens, Johannesburg, 30 December

1980. Interview by Eddie Koch, Johannesburg, 22 June

1984. Author's interview, Johannesburg, 3 June

1985. Author's interview, Johannesburg, 23 June

Silgee, Wilson. 1979a. Interview by Tim Couzens, Johannesburg, 15 March

1979b. Interview by Eddie Koch, Johannesburg, 11 September

1986. Interview by MEDU, Gaborone, July 1982, published in Rixaka, 3

Sililo, Edward. 1986. Author's interview, Johannesburg, 1 December

Sole, Kelwyn. 1984. 'Black literature and performance: some notes on class and populism', South African Labour Bulletin, 9/8, July

Tirro, Frank. 1979. Jazz: A History (London) 